Check for updates

Cite this: RSC Adv., 2018, 8, 2795

Received 19th December 2017 Accepted 5th January 2018

DOI: 10.1039/c7ra13481a

rsc.li/rsc-advances

\section{Radical-initiated alkene hydroauration as a route to gold(III) alkyls: an experimental and computational study $\dagger$}

\begin{abstract}
Anna Pintus (D) $\ddagger$ and Manfred Bochmann (D) *
The hydroauration of functionalised 1-alkenes by the gold(III) hydride $\left(\mathrm{C}^{\wedge} \mathrm{N}^{\mathrm{OMe} \wedge} \wedge\right) \mathrm{AuH}$ is initiated by organic radicals and proceeds via $\left(C^{\wedge} N^{\wedge} \mathrm{C}\right) A u(\|)$ radical intermediates following a bimolecular outer-sphere mechanism. The outcome of these reactions is determined by the stability of the gold-substituted radicals, and chemoselectivity correlates with the degree of spin delocalisation in the alkylgold radical intermediates. The reaction is sensitive to steric as well as electronic factors; disubstituted alkenes and alkenes that form unstable radicals give product mixtures or are unreactive. As DFT calculations show, the reactions agree well with the calculated reaction enthalpies and the standard free energy change for the reaction of the gold(II) radical with the respective alkene.
\end{abstract}

\section{Introduction}

We recently reported the synthesis of the first example of a gold(III) hydride complex $\left(\mathrm{C}^{\wedge} \mathrm{N}^{\wedge} \mathrm{C}\right) \mathrm{AuH}$, based on the stabilisation provided by a $\mathrm{C}^{\wedge} \mathrm{N}^{\wedge} \mathrm{C}$ pincer ligand framework $\left[\left(\mathrm{C}^{\wedge} \mathrm{N}^{\wedge} \mathrm{C}\right)\right.$ $=2,6-\left(\mathrm{C}_{6} \mathrm{H}_{3} \mathrm{Bu}^{t}\right)_{2}$ pyridine]. ${ }^{1}$ Cyclometallated $\mathrm{C}^{\wedge} \mathrm{N}^{\wedge} \mathrm{C}$ pincer complexes of gold(III) $)^{2,3}$ have proved particularly useful for the stabilisation of otherwise non-isolable species, including gold(III) alkene, ${ }^{4}$ alkyne, ${ }^{5} \mathrm{CO}^{6}$ and peroxide complexes. ${ }^{7}\left(\mathrm{C}^{\wedge} \mathrm{N}^{\wedge} \mathrm{C}\right)$ $\mathrm{AuH}$ proved to be thermally stable and did not react with air, moisture or even acetic acid and was also unreactive to alkenes and alkynes. On the other hand, it did react with allenes to give gold vinyl complexes in high yield. ${ }^{1}$ This lack of reactivity is not entirely unsurprising: gold(III) adheres strictly to a squareplanar coordination geometry and in $\left(\mathrm{C}^{\wedge} \mathrm{N}^{\wedge} \mathrm{C}\right) \mathrm{AuH}$ all four coordination sites are occupied, so that these pincer compounds lack the ability to bind unsaturated substrates. However, we discovered that alternative reaction pathways become accessible in the presence of traces of organic radicals capable of abstracting the hydrogen ligand and thus generating $\left(\mathrm{C}^{\wedge} \mathrm{N}^{\wedge} \mathrm{C}\right) \mathrm{Au}(\mathrm{II})^{\vee}$ radical species. These $\mathrm{Au}(\mathrm{II})$ radicals can readily bind alkynes and lead to alkyne hydroauration in a bimolecular outer-sphere process (Scheme 1). Increasing the concentration of radicals greatly increases the rate of insertion reactions into $\mathrm{Au}-\mathrm{H}$ bonds. This pathway allows the hydroauration of a range of substituted alkynes to give (Z)-vinylgold complexes $\left(\mathrm{C}^{\wedge} \mathrm{N}^{\wedge} \mathrm{C}\right)$

School of Chemistry, University of East Anglia, Norwich Research Park, Norwich NR4 7TJ, UK. E-mail: m.bochmann@uea.ac.uk; Tel: +44(0)-1603-592044

$\dagger$ Electronic supplementary information (ESI) available. See DOI: 10.1039/c7ra13481a

\$ Present address: Dipartimento di Scienze Chimiche e Geologiche, Università degli Studi di Cagliari, S.S. 554 Bivio per Sestu, 09042 Monserrato (CA), Italy.
$\mathrm{Au}-\mathrm{C}\left(\mathrm{R}^{1}\right)=\mathrm{CH}\left(\mathrm{R}^{2}\right)$ with almost quantitative stereo- and regioselectivity. These reactions are tolerant of a large variety of functional groups including hydroxide and carboxylic acid functions. ${ }^{8}$ There is a growing realisation of the role that singleelectron transfer steps and gold(II) intermediates may play in gold-mediated reactions. ${ }^{9}$

We report here on the reactivity of in situ generated gold(II) radicals with 1-alkenes, which leads to the formation of gold(III) alkyl complexes. Alkyl complexes of $\mathrm{C}^{\wedge} \mathrm{N}^{\wedge} \mathrm{C}$ gold pincer complexes are accessible in a variety of ways: by alkylation with Grignard reagents or aluminium alkyls, ${ }^{10-12}$ by O-abstraction from $\left(\mathrm{C}^{\wedge} \mathrm{N}^{\wedge} \mathrm{C}\right) \mathrm{AuOMe}$ with phosphines ${ }^{13}$ or by the reaction of $\left(\mathrm{C}^{\wedge} \mathrm{N}^{\wedge} \mathrm{C}\right) \mathrm{AuOH}$ with allylic alcohols,${ }^{13}$ or by the reaction of $\left(\mathrm{C}^{\wedge} \mathrm{N}^{\wedge} \mathrm{C}\right) \mathrm{AuCl} /$ base with $\mathrm{C}-\mathrm{H}$ acidic alkanes $\mathrm{CH}_{2} \mathrm{R}^{1} \mathrm{R}^{2}$. This last method is very versatile and gives alkyls $\left(\mathrm{C}^{\wedge} \mathrm{N}^{\wedge} \mathrm{C}\right) \mathrm{AuCHR}{ }^{1} \mathrm{R}^{2}$ which carry functional groups in the $\alpha$-position. ${ }^{12}$ Here we

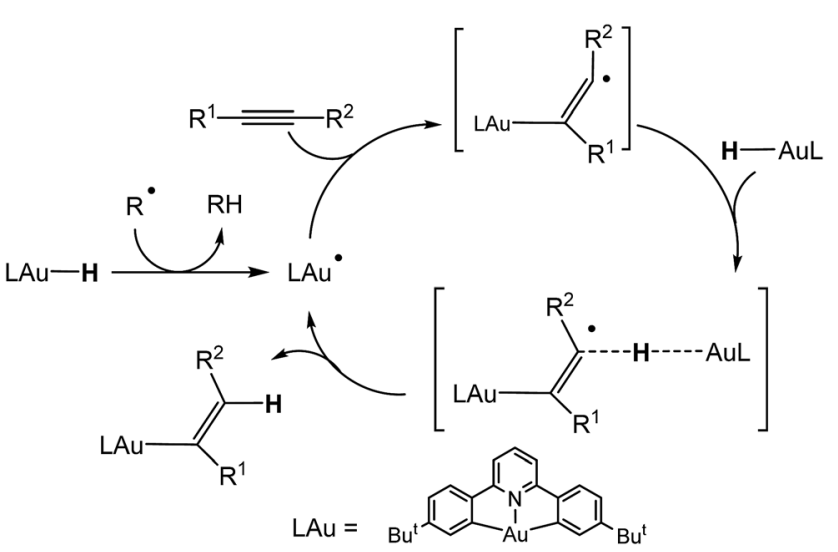

Scheme 1 Mechanism of radical-mediated alkyne hydroauration with $\left(C^{\wedge} N^{\wedge} \mathrm{C}\right)$ AuH pincer complexes. ${ }^{8}$ 
describe the hydroauration of alkenes to give gold(III) alkyls with functional groups in $\beta$-position. The experimental and computational results provide insights into the factors influencing radical-based hydroaurations of unsaturated substrates.

\section{Results and discussion}

For solubility reasons, from the library of differently substituted $\mathrm{C}^{\wedge} \mathrm{N}^{\wedge} \mathrm{C}$ gold(III) hydrides previously reported, ${ }^{1,8}$ we chose to carry out the reactions reported here using the $p$-OMe substituted gold hydride, $\left(\mathrm{C}^{\wedge} \mathrm{N}^{\mathrm{OMe}}{ }^{\wedge} \mathrm{C}\right) \mathrm{AuH}(\mathbf{1})$. This compound is accessible following literature procedures from $\left(\mathrm{C}^{\wedge} \mathrm{N}^{\mathrm{OMe}}{ }^{\wedge} \mathrm{C}\right)$ AuCl and $\mathrm{LiAlH}_{4}$ in $85 \%$ yield.

The reactivity of this complex towards different alkenes was investigated initially through scoping experiments carried out on a small scale, by mixing micromolar quantities of $\mathbf{1}$ and stoichiometric amounts of the alkene in toluene- $d_{8}$ in a J-Young NMR tube (Scheme 2). Two molar equivalents of azobisisobutyronitrile (AIBN) were added, the mixture was shaken and heated in the dark to $50{ }^{\circ} \mathrm{C}$ to induce the decomposition of AIBN. The progress of the alkene hydroaurations was monitored by ${ }^{1} \mathrm{H}$ NMR spectroscopy. At the end of the reaction the volatile components were removed in vacuo, the residue was washed with $n$-hexane followed by $\mathrm{MeOH}$ to remove any unreacted alkene and excess AIBN, and the residue was dissolved in $\mathrm{CD}_{2} \mathrm{Cl}_{2}$. The product was characterized spectroscopically. This method led to the formation of the alkyls 2-8 in high yields.

For the alkenes $\mathrm{CH}_{2}=\mathrm{CHR}[\mathrm{R}=\mathrm{CN}$, COOMe, COOH, Ph, 2$\left.\mathrm{MeC}_{6} \mathrm{H}_{4}, 3-\mathrm{MeC}_{6} \mathrm{H}_{4}, \mathrm{C}(\mathrm{O}) \mathrm{Me}\right]$ this resulted in the clean and facile formation of the corresponding gold-alkyl products 2-8. These reactions were also conducted on a preparative scale and allowed the isolation of the gold alkyls $\mathbf{2 - 8}$ as microcrystalline powders in moderate yields, with losses being mainly due to the washing steps during purification. Attempts to obtain crystals suitable for X-ray diffraction were unfortunately not successful.

However, another series of alkenes gave slow reactions that led to mixtures of products which could not be purified. This behaviour was shown by unfunctionalised alkenes (1-pentene and 1-hexene), by allylic derivatives $\mathrm{CH}_{2}=\mathrm{CHR}\left(\mathrm{R}=\mathrm{CH}_{2} \mathrm{OH}\right.$, $\mathrm{CH}_{2} \mathrm{NH}_{2}, \mathrm{CH}_{2} \mathrm{COOH}$ ), and by more highly substituted and internal alkenes, notably 1,1-diphenylethene, $\alpha$-methylstyrene, p-tert-butylstyrene, 2-methyl-3-butenol and 3-pentenoic acid. Finally, cis- and trans-stilbene, cis- and trans-2-pentene and cyclopentene proved entirely unreactive.

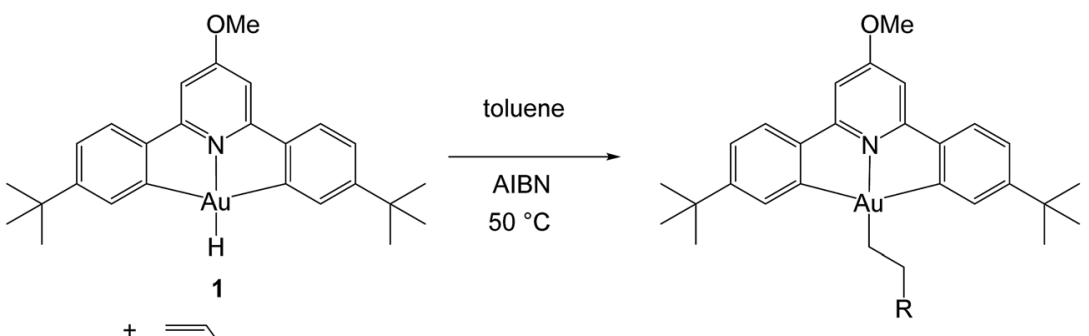

$2, \mathrm{R}=\mathrm{CN} ; 3, \mathrm{R}=\mathrm{COOMe} ; 4, \mathrm{R}=\mathrm{COOH} ; \mathbf{5}, \mathrm{R}=\mathrm{C}_{6} \mathrm{H}_{5} ;$

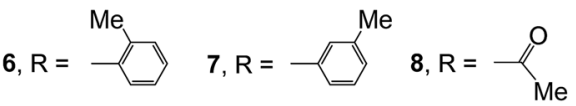

Scheme 2 Synthesis of gold(III) alkyls 2-8 from the gold(II) hydride 1.

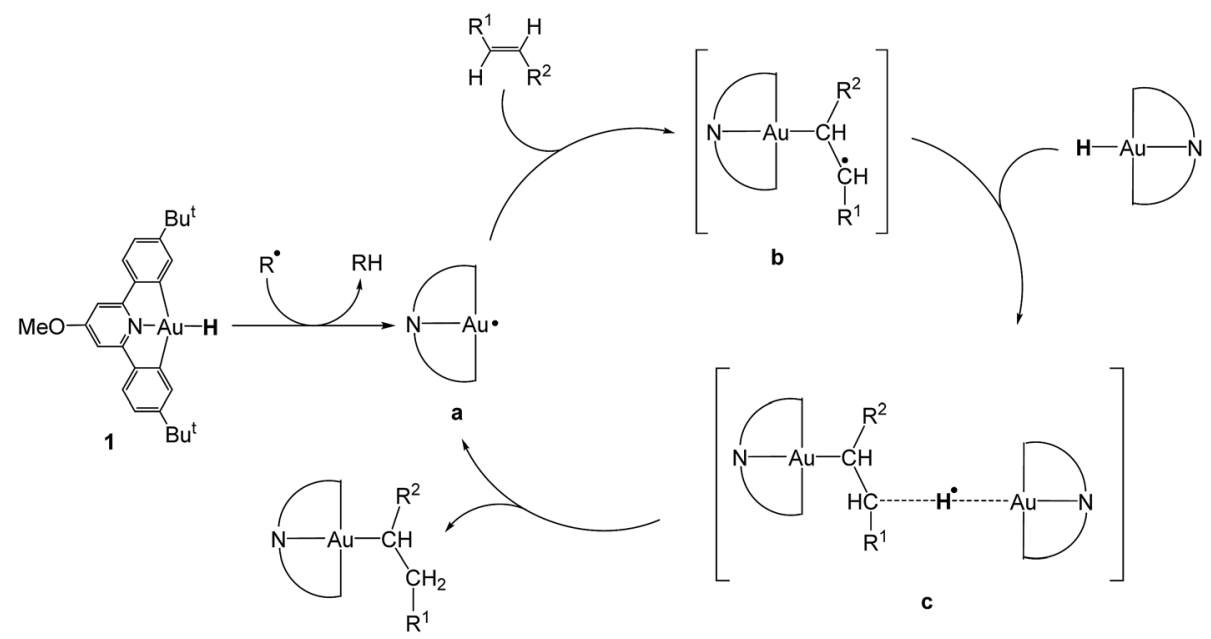

Scheme 3 Proposed mechanism for the radical-initiated hydroauration of alkenes by 1 . 
Table 1 Standard reaction enthalpies $\left(\Delta H_{\mathrm{r}}^{\circ}\right)$, Gibbs free energy of reaction $\left(\Delta G_{\mathrm{r}}^{\circ}\right)$, and total electronic energy differences $\left(\Delta E_{\mathrm{tot}}\right)$ calculated in the gas phase at $298 \mathrm{~K}$ for the formation of gold(III) alkyl, vinyl and allenyl radicals from the corresponding unsaturated substrates and a* (Scheme 3 )

\begin{tabular}{|c|c|c|c|c|c|}
\hline b1* & $\mathrm{CN}$ & $\mathrm{H}$ & -18.68 & -6.52 & -19.61 \\
\hline b2* & COOMe & $\mathrm{H}$ & -16.84 & -4.25 & -17.86 \\
\hline b3* & $\mathrm{COOH}$ & $\mathrm{H}$ & -17.03 & -4.47 & -18.04 \\
\hline b4* & $\mathrm{Ph}$ & $\mathrm{H}$ & -18.50 & -5.79 & -19.34 \\
\hline b5* & $\mathrm{C}(\mathrm{O}) \mathrm{Me}$ & $\mathrm{H}$ & -17.85 & -5.11 & -19.04 \\
\hline b6* & $\mathrm{CH}_{2} \mathrm{OH}$ & $\mathrm{H}$ & -13.59 & -1.31 & -14.07 \\
\hline b9* & $n$-Pr & $\mathrm{H}$ & -11.32 & 0.92 & -11.83 \\
\hline b10* & $n-\mathrm{Bu}$ & $\mathrm{H}$ & -11.26 & 0.87 & -11.81 \\
\hline b11* & $\mathrm{Ph}$ & $\mathrm{Ph}$ & -11.70 & 1.94 & -12.30 \\
\hline b12* & $\mathrm{Me}$ & Et & -7.33 & 4.89 & -7.95 \\
\hline b13* & Et & $\mathrm{Me}$ & -7.56 & 4.36 & -8.06 \\
\hline b14* & $\mathrm{Me}$ & $\mathrm{CH}_{2} \mathrm{COOH}$ & -8.32 & 4.78 & -8.84 \\
\hline d4* & $\mathrm{Ph}$ & $\mathrm{Me}$ & -17.11 & -6.09 & -18.36 \\
\hline d5* & $\mathrm{SiMe}_{3}$ & $\mathrm{H}$ & -17.46 & -6.36 & -18.48 \\
\hline h1* & $\mathrm{Me}$ & $\mathrm{Me}$ & -29.18 & -16.22 & -29.23 \\
\hline
\end{tabular}

There were therefore two classes of alkenes: those that gave clean insertions into the $\mathrm{Au}-\mathrm{H}$ bond, and those that showed borderline or no reactivity. In order to rationalize the reactivity differences observed for the various alkene substrates, a computational investigation was undertaken using density functional theory (DFT). ${ }^{\mathbf{1 4}}$ It is proposed that the mechanism of alkene hydroauration follows the principles previously established for the correspondent alkyne reactions, ${ }^{8}$ as shown in Scheme 3 , and involves various radical intermediates $\mathbf{a}, \mathbf{b}$ and $\mathbf{c}$.

Our calculations focussed on the first step of the mechanism described above, the formation of the intermediate radical species $\mathbf{b}^{*}$ from the gold(II) radical $\mathbf{a}^{*}$ and the alkene substrate. The model for the pincer ligand was simplified by omitting the $\mathrm{Bu}^{t}$ and $\mathrm{OMe}$ substituents (denoted by *). The energetics of this reaction step were investigated by calculating the standard

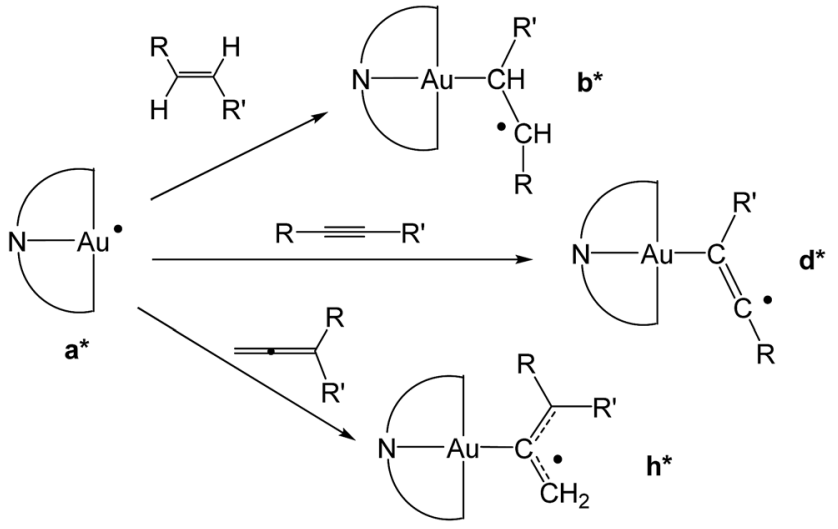

Scheme 4 Formation of differently substituted alkyl, vinyl and allyl radicals through the reaction of the gold(II) species a* with alkene, alkyne and allene substrates, respectively. reaction enthalpies $\left(\Delta H_{\mathrm{r}}^{\circ}\right)$, Gibbs free energy of reaction $\left(\Delta G_{\mathrm{r}}^{\circ}\right)$ and the total electronic energy differences $\left(\Delta E_{\text {tot }}\right)$ in the gas phase and under standard conditions.

Very similar trends were calculated for the three parameters taken into consideration (see Table 1). In particular, the calculated values of $\Delta G_{\mathrm{r}}^{\circ}$ reflect the experimental observations quite accurately: the formation of alkyl radicals b1*-b5* is energetically favourable, as observed by the clean, near-quantitative formation of gold alkyls in these cases, while reactions leading to $\mathbf{b 6} *-\mathbf{b} 15 *$ are close to $\Delta G_{\mathrm{r}}^{\circ}=0$ or positive and are therefore not predicted to proceed.

To provide a further insight into the observed trends, the calculations were extended to the previously investigated alkyne $^{8}$ and allene ${ }^{1}$ substrates, and in particular to the formation of some of the corresponding vinyl and allyl radicals $\mathbf{d}^{*}$ and $\mathbf{h}^{*}$, respectively, from the reaction with $\mathbf{a}^{*}$ (Scheme 4 ). For all of these systems, the calculated values of $\Delta H_{\mathrm{r}}^{\circ}, \Delta E_{\text {tot }}$ and $\Delta G_{\mathrm{r}}^{\circ}$ were more negative than in the case of the alkene substrates (Table 1 and Fig. 1). The reaction with allenes to give the allyl radical h1* proved energetically particularly favourable, in agreement with the experimentally observed facile hydroauration of allenes by $\left(\mathrm{C}^{\wedge} \mathrm{N}^{\wedge} \mathrm{C}\right)$ AuH. ${ }^{1}$ The formation of the vinyl radical $\mathbf{d} \mathbf{1}^{*}$ is also strongly exergonic, while there is little energy difference between the other mono- and disubstituted alkynes in this series.

The chemoselectivity of the hydroauration was explored using the enynes 9 and 10 (Scheme 5), under analogous AIBNinitiated conditions. NMR spectroscopy showed that product mixtures are formed from attack on both the double and triple bonds, which in the case of 9 occurred with about equal probability, while 10 gave an approximately $80: 20$ mixture with predominant attack on $\mathrm{C}=\mathrm{C}$. In agreement with this, calculations of the reaction of species $\mathbf{a}^{*}$ with 2-methylbuten-3-yne 


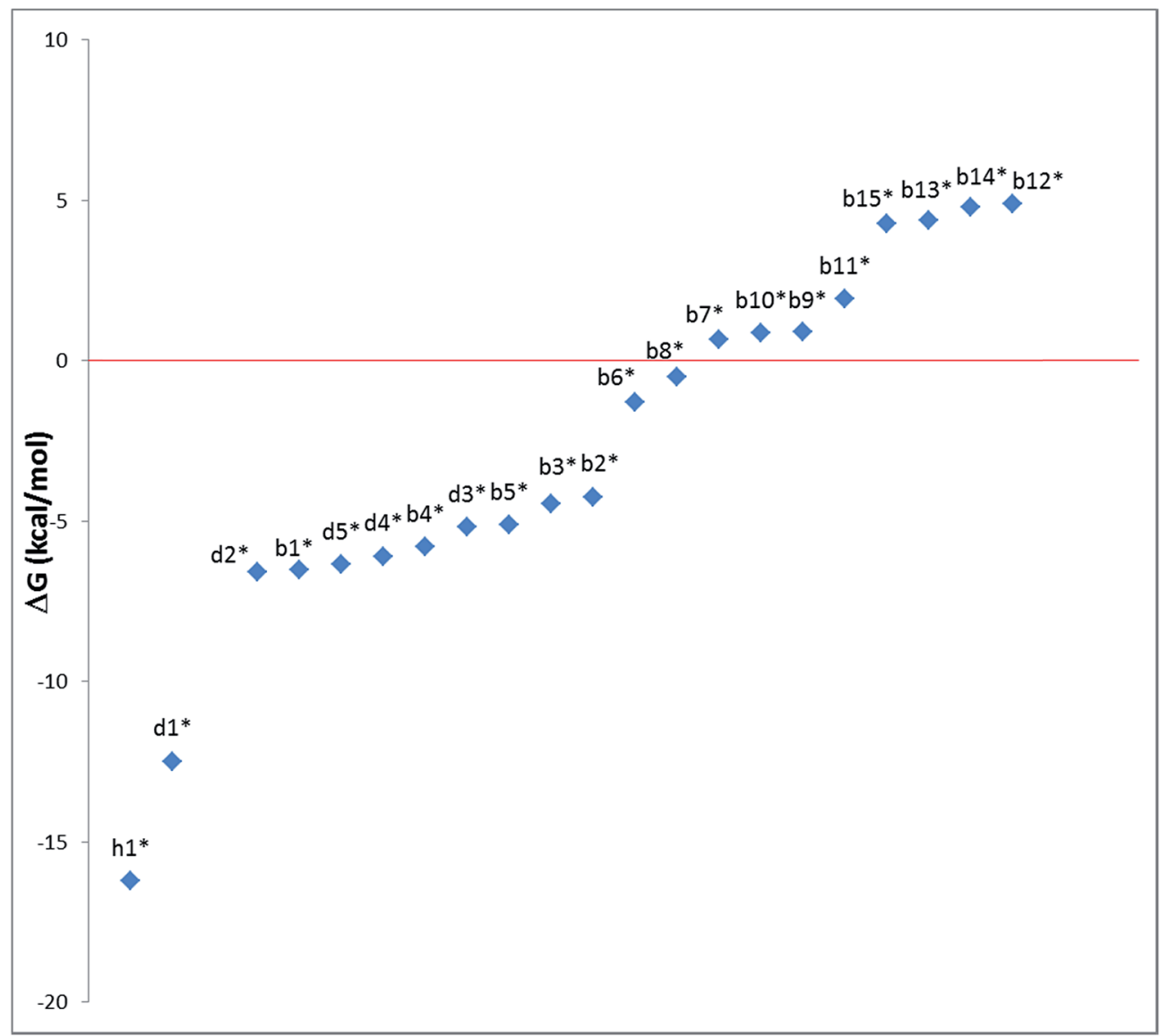

Fig. 1 Trend of $\Delta G_{\mathrm{r}}^{\circ}(T=298 \mathrm{~K})$ calculated for the reactions depicted in Scheme $3\left(\mathrm{kcal} \mathrm{mol}^{-1}\right)$. The substituents for the radical species b1*-b15*, $\mathrm{d} 1 *-\mathrm{d} 5 *$ and $\mathrm{h} 1 *$ are as listed in Table 1.

showed essentially identical $\Delta E_{\text {tot }}$ values for the formation of

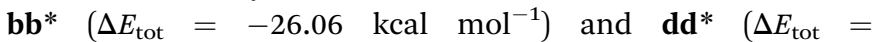
$-26.11 \mathrm{kcal} \mathrm{mol}^{-1}$ ) (Scheme 5).

In order to rationalize observed alkene reactivity pattern, an investigation of the spin density in different $\mathbf{b}^{*}, \mathbf{d}^{*}$ and $\mathbf{h}^{*}$ radical intermediates was performed. As summarized in Fig. 2,

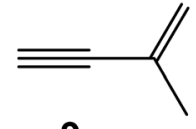

9

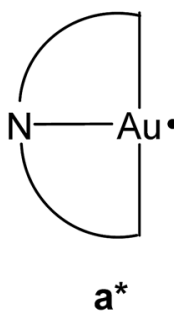

$\mathbf{a}^{*}$

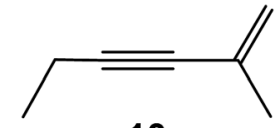

10

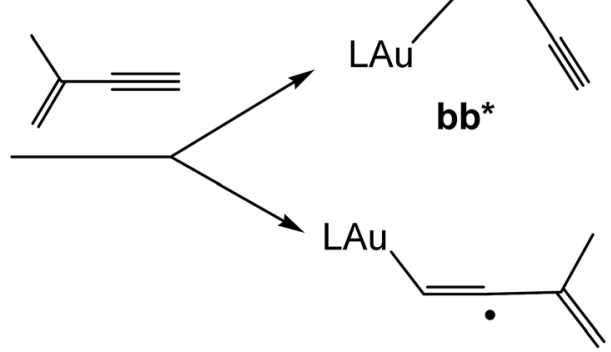

$\mathbf{d d}^{*}$ in radicals b1*-b5*, d1*, and $\mathbf{h} \mathbf{1}^{*}$ a significant degree of spin delocalization is observed, while such delocalization does not arise in $\mathbf{b 6} \mathbf{6}^{*}-\mathbf{b} 10^{*}$. This suggests that the reason for the energy difference in the formation of radicals on reaction with the gold(II) species reflects these differences in spin delocalisation, the most stable radical intermediates being those stabilized by resonance. Accordingly, all of the alkyne and allene substrates previously explored, ${ }^{1,8}$ whose radicals can in all cases be stabilized by resonance, were observed to undergo facile hydroauration, while for the alkenes the reactivity depends on the nature of the substituent.

\section{Conclusion}

The hydroauration of 1-alkenes with the gold(III) hydride pincer complex $\left(\mathrm{C}^{\wedge} \mathrm{N}^{\mathrm{OMe}}{ }^{\wedge} \mathrm{C}\right) \mathrm{AuH}$ is initiated by radicals and appears to follow the same bimolecular outer-sphere mechanism that has previously been established for the regio- and stereoselective hydroauration of alkynes. The process involves the generation of a $\left(\mathrm{C}^{\wedge} \mathrm{N}^{\wedge} \mathrm{C}\right) \mathrm{Au}(\mathrm{II})$ radical which reacts with alkenes to give a gold-substituted alkyl radical. According to DFT calculations, the determining factor for the reaction appears to be the energy change associated with the attack by a gold(II) radical species on the alkene. Alkenes leading to alkyl radicals with restricted spin

Scheme 5 Reactions with enynes. 


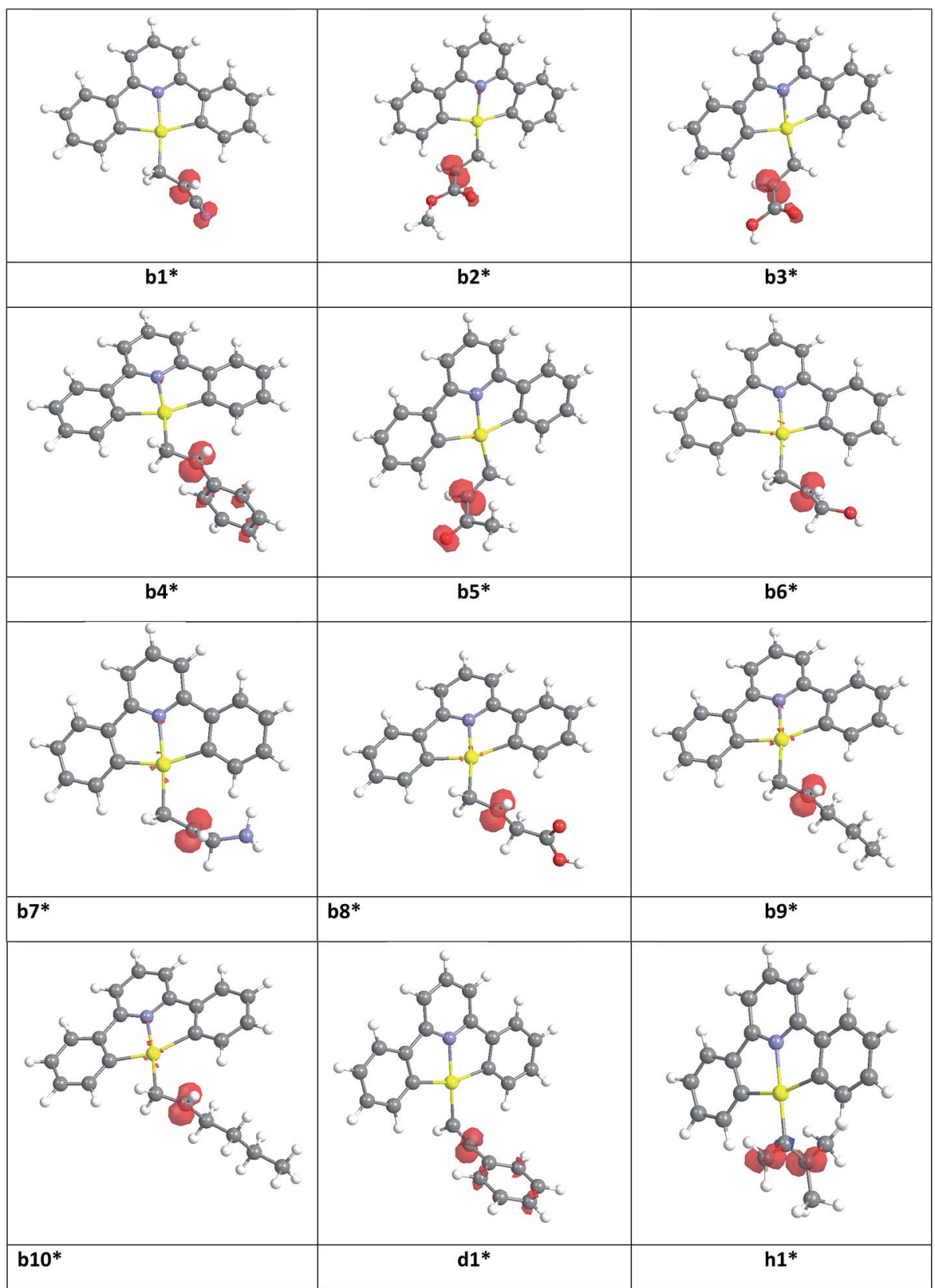

Fig. 2 Spin density maps for radical species b1*-b10*, d1* and h1*.

delocalisation either reacted slowly to a mixture of products, or did not react at all. While this limits the scope of the method to some extent, the hydroauration of activated alkenes is a facile method for the metal alkyl-free generation of gold(III) alkyl complexes bearing a variety of functional groups in $\beta$-position, including cyano, keto, ester and carboxylic acid functions. Moreover, the present study suggests that the hydroauration by gold(III) hydrides can be extended to different classes of unsaturated species, and that the reactivity trend of different substrates can be rationalized and/or predicted based on the spin delocalization of the radical intermediates involved. The scope of such alkyls for $\mathrm{C}\left(\mathrm{sp}^{2}\right)-\mathrm{C}\left(\mathrm{sp}^{3}\right)$ coupling reactions by reductive elimination using (aryl)(alkyl)gold(III) complexes is currently under investigation.

\section{Experimental}

When required, manipulations were performed by using standard Schlenk techniques under dry nitrogen or a MBraun glove box. Nitrogen was purified by passing through columns of supported $\mathrm{P}_{2} \mathrm{O}_{5}$ with moisture indicator, and of activated $4 \AA$ molecular sieves. Anhydrous solvents were freshly distilled from appropriate drying agents. Elemental analyses were carried out at London Metropolitan University. AIBN (BDH Chemicals) was degassed by evacuation and stored under $\mathrm{N}_{2}$ in the glovebox before use. The alkenes (Sigma Aldrich) were degassed by freeze-pump-thaw cycles and stored over activated $4 \AA$ molecular sieves before use. Solvents, toluene- $d_{8}$ and $\mathrm{CD}_{2} \mathrm{Cl}_{2}$ (Apollo 
Scientific) were degassed by three freeze-pump-thaw cycles and stored over activated $4 \AA$ molecular sieves prior to use. ${ }^{1} \mathrm{H}$ and ${ }^{13} \mathrm{C}$ $\left\{{ }^{1} \mathrm{H}\right\}$ NMR spectra were recorded using a Bruker Avance DPX-300 spectrometer equipped with a ${ }^{1} \mathrm{H}$, BB smartprobe. ${ }^{1} \mathrm{H}$ NMR spectra (300.13 MHz) were referenced to the residual protons of the deuterated solvent used. ${ }^{13} \mathrm{C}\left\{{ }^{1} \mathrm{H}\right\}$ NMR spectra (75.47 MHz) were referenced to the D-coupled ${ }^{13} \mathrm{C}$ resonances of the NMR solvent.

\section{Preparation of $\left(\mathrm{C}^{\wedge} \mathrm{N}^{\mathrm{OMe}}{ }^{\wedge} \mathrm{C}\right) \mathrm{AuH}(1)$}

Complex 1 was prepared by a modification of a literature procedure. ${ }^{8}$ Under a $\mathrm{N}_{2}$ atmosphere, $0.40 \mathrm{~g}(0.66 \mathrm{mmol})$ of the chloro complex $\left(\mathrm{C}^{\wedge} \mathrm{N}^{\mathrm{OMe}}{ }^{\wedge} \mathrm{C}\right) \mathrm{AuCl}$ was charged in a dry Schlenk flask with $40 \mathrm{~mL}$ of dry toluene. The mixture was cooled to $-78{ }^{\circ} \mathrm{C}$ and a solution of $\mathrm{LiAlH}_{4}$ in dry THF $(0.05 \mathrm{M}, 13 \mathrm{~mL}, 0.66$ mmol) was added dropwise. The mixture was stirred at $-78{ }^{\circ} \mathrm{C}$ in the dark for 15 min, yielding a dark suspension which was filtered under $\mathrm{N}_{2}$. The filtrate was evaporated to dryness to afford a brown powder. This was taken up in dichloromethane, and the resulting suspension was filtered over cotton in the dark, to give a pale-yellow filtrate. The solvent was removed under reduced pressure, and a white solid was obtained, yield $0.38 \mathrm{~g}$ (0.56 mmol, 85\%).

\section{Synthesis and characterization of insertion products 2-8}

NMR scale reactions. As a general procedure, a solution of $\mathbf{1}$ $(0.009 \mathrm{mmol})$ in toluene- $d_{8}(0.7 \mathrm{~mL})$ was prepared inside a glovebox in a J-Young NMR tube. The desired olefin (1 molar equivalent) was then added using a microlitre syringe, followed by 2 equivalents of AIBN. The tube was shaken and heated in the dark to $50{ }^{\circ} \mathrm{C}$. The reactions were monitored by ${ }^{1} \mathrm{H}$ NMR spectroscopy. The volatile components were removed in vacuo at the end of the reaction, and the residue was washed with $n$-hexane and with $\mathrm{MeOH}$, and eventually redissolved in $\mathrm{CD}_{2} \mathrm{Cl}_{2}$ for the NMR characterization. Yields were calculated from the NMR integration.

$\left(\mathbf{C}^{\wedge} \mathbf{N}^{\mathrm{OMe}}{ }_{\wedge} \mathbf{C}\right) \mathbf{A u}\left(\mathbf{C H}_{2}\right)_{2} \mathbf{C N}$ (2). This compound was synthesized from $1(5.0 \mathrm{mg}, 0.009 \mathrm{mmol})$, acrylonitrile $(6 \mu \mathrm{L}$ of a $1.5 \mathrm{M}$ solution in toluene- $\left.d_{8}, 0.009 \mathrm{mmol}\right)$ and $3 \mathrm{mg}$ of AIBN (0.018 $\mathrm{mmol})$. The reaction was complete after $75 \mathrm{~min}$ at $50{ }^{\circ} \mathrm{C}$. Yield: $80 \%$.

$\left(\mathrm{C}^{\wedge} \mathbf{N}^{\mathrm{OMe}}{ }^{\wedge} \mathbf{C}\right) \mathbf{A u}\left(\mathrm{CH}_{2}\right)_{2} \mathbf{C O O M e}$ (3). This compound was made from $1(5.0 \mathrm{mg}, 0.009 \mathrm{mmol})$, methyl acrylate $(6 \mu \mathrm{L}$ of a $1.5 \mathrm{M}$ solution in toluene- $\left.d_{8}, 0.009 \mathrm{mmol}\right)$ and $3 \mathrm{mg}$ of AIBN (0.018 $\mathrm{mmol})$. Conversion was complete after $50 \mathrm{~min}$ at $50{ }^{\circ} \mathrm{C}$. Yield: $90 \%$.

$\left(\mathbf{C}^{\wedge} \mathbf{N}^{\mathbf{O M e}}{ }^{\wedge} \mathbf{C}\right) \mathbf{A u}\left(\mathbf{C H}_{2}\right)_{2} \mathbf{C O O H}(4)$. This compound was made from $1(5.0 \mathrm{mg}, 0.009 \mathrm{mmol})$, acrylic acid $(10 \mu \mathrm{L}$ of a $0.9 \mathrm{M}$ solution in toluene- $\left.d_{8}, 0.009 \mathrm{mmol}\right)$ and $3 \mathrm{mg}$ of AIBN (0.018 $\mathrm{mmol}$ ). Conversion was complete after $30 \mathrm{~min}$ at $50{ }^{\circ} \mathrm{C}$. Yield: $90 \%$.

$\left(\mathbf{C}^{\wedge} \mathbf{N}^{\mathrm{OMe}}{ }^{\wedge} \mathbf{C}\right) \mathbf{A u}\left(\mathbf{C H}_{2}\right)_{2} \mathbf{P h}(5)$. This compound was made from $1(5.0 \mathrm{mg}, 0.009 \mathrm{mmol})$, styrene $(10 \mu \mathrm{L}$ of a $0.9 \mathrm{M}$ solution in toluene- $\left.d_{8}, 0.009 \mathrm{mmol}\right)$ and $3 \mathrm{mg}$ of AIBN $(0.018 \mathrm{mmol})$. Conversion was complete after $10 \mathrm{~h}$ at $50{ }^{\circ} \mathrm{C}$. Yield: $85 \%$.

$\left(\mathrm{C}^{\wedge} \mathbf{N}^{\mathrm{OMe}}{ }^{\wedge} \mathrm{C}\right) \mathrm{Au}\left(\mathrm{CH}_{2}\right)_{2}\left(\mathbf{2}-\mathrm{MeC}_{6} \mathrm{H}_{4}\right)$ (6). This compound was made from $1(5.0 \mathrm{mg}, 0.009 \mathrm{mmol})$, 2-methylstyrene $(10 \mu \mathrm{L}$ of a $0.9 \mathrm{M}$ solution in toluene- $d_{8}, 0.009 \mathrm{mmol}$ ) and $3 \mathrm{mg}$ of AIBN (0.018 mmol). Conversion was complete after $31 \mathrm{~h}$ at $50{ }^{\circ} \mathrm{C}$. Yield: $90 \%$.

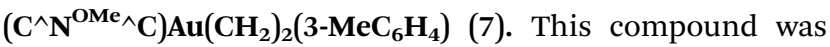
made from 1 (5.0 mg, $0.009 \mathrm{mmol})$, 3-methylstyrene (10 $\mu \mathrm{L}$ of a $0.9 \mathrm{M}$ solution in toluene- $d_{8}, 0.009 \mathrm{mmol}$ ) and $3 \mathrm{mg}$ of AIBN (0.018 mmol). Conversion was complete after $13 \mathrm{~h}$ at $50{ }^{\circ} \mathrm{C}$. Yield: $90 \%$.

$\left(\mathbf{C}^{\wedge} \mathbf{N}^{\mathbf{O M e}}{ }^{\wedge} \mathbf{C}\right) \mathbf{A u}\left(\mathbf{C H}_{2}\right)_{2} \mathbf{C}(\mathbf{O}) \mathbf{M e}(\mathbf{8})$. This compound was made from $1(5.0 \mathrm{mg}, 0.009 \mathrm{mmol}), 3$-buten-2-one $(10 \mu \mathrm{L}$ of a $0.9 \mathrm{M}$ solution in toluene- $\left.d_{8}, 0.009 \mathrm{mmol}\right)$ and $3 \mathrm{mg}$ of AIBN $(0.018$ $\mathrm{mmol}$ ). Conversion was complete after $5 \mathrm{~h}$ at $50{ }^{\circ} \mathrm{C}$. Yield: $90 \%$.

Reactions on a preparative scale. As a general procedure, to a solution of $1(0.07 \mathrm{mmol})$ in dry and degassed toluene $(4 \mathrm{~mL})$ under nitrogen was added 1 molar equivalent of the desired olefin using a microlitre syringe, followed by 1 equivalent of AIBN. The mixture was heated in the dark to $50{ }^{\circ} \mathrm{C}$. The reactions were monitored by ${ }^{1} \mathrm{H}$ NMR spectroscopy. The volatile components were removed in vacuo at the end of the reaction, and the residue was washed with $n$-hexane and with $\mathrm{MeOH}$.

$\left(\mathrm{L}^{\mathrm{OMe}}\right) \mathrm{Au}\left(\mathrm{CH}_{2}\right)_{2} \mathrm{CN}$ (2).

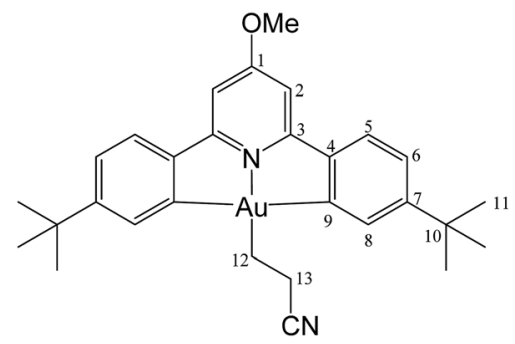

The compound was synthesized from 1 (40.0 $\mathrm{mg}, 0.07 \mathrm{mmol})$, acrylonitrile $(5 \mu \mathrm{L}, 0.07 \mathrm{mmol})$ and $11.0 \mathrm{mg}$ of AIBN $(0.007 \mathrm{mmol})$, and the reaction resulted complete after $2 \mathrm{~h}$ at $50{ }^{\circ} \mathrm{C}$. Yield: $20.0 \mathrm{mg}(0.03 \mathrm{mmol}), 45 \%$. Anal. calcd for $\mathrm{C}_{29} \mathrm{H}_{33} \mathrm{AuN}_{2} \mathrm{O}$ : C, 55.95; $\mathrm{H}, 5.34 ; \mathrm{N}, 4.50$. Found: C, 55.41; H, 5.11; N, 5.04. ${ }^{1} \mathrm{H}-\mathrm{NMR}$ (300.13 MHz, $\mathrm{CD}_{2} \mathrm{Cl}_{2}$ ): 7.70 (d, 2H, $\left.{ }^{4} J=1.8 \mathrm{~Hz}, \mathrm{H} 8\right), 7.57$ (d, $\left.2 \mathrm{H},{ }^{3} \mathrm{~J}=8.1 \mathrm{~Hz}, \mathrm{H} 5\right), 7.30\left(\mathrm{dd}, 2 \mathrm{H},{ }^{3} J=8.1,{ }^{4} \mathrm{~J}=1.8 \mathrm{~Hz}, \mathrm{H} 6\right), 6.96$ (s, 2H, H2), 4.01 (s, 3H, OMe), 2.89 (t, 2H, $\left.{ }^{3} J=8.0 \mathrm{~Hz}, \mathrm{H} 12\right), 2.08$ (t, 2H, $\left.{ }^{3} J=8.0 \mathrm{~Hz}, \mathrm{H} 13\right), 1.38 \mathrm{ppm}(\mathrm{s}, 18 \mathrm{H}, \mathrm{H} 11) .{ }^{13} \mathrm{C}\left\{{ }^{1} \mathrm{H}\right\} \mathrm{NMR}$ (75.47 MHz, $\mathrm{CD}_{2} \mathrm{Cl}_{2}$ ): $\delta 170.6$ (s, C1), 166.7 (s, C9), 164.4 (s, C3), 154.4 (s, C7), 148.2 (s, C4), 130.1 (s, C8), 125.2 (s, C5), 123.7 (s, C6), 122.2 (s, CN), 102.4 (s, C2), 56.5 (s, OMe), 35.6 (s, C10), 31.4 (s, C11), 18.9 (s, C12), 16.7 ppm (s, C13).

$\left(\mathrm{C}^{\wedge} \mathrm{N}^{\mathrm{OMe}}{ }_{\wedge} \mathrm{C}\right) \mathrm{Au}\left(\mathrm{CH}_{2}\right)_{2} \mathrm{COOMe}(3)$.

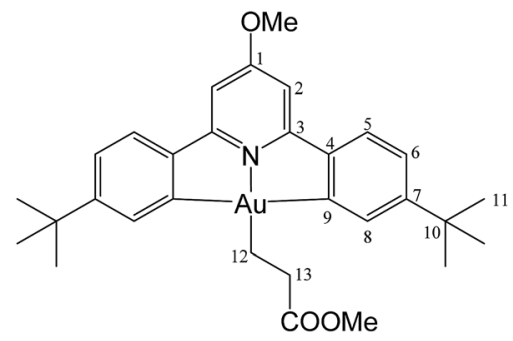

This compound was synthesized from 1 (40.0 mg, 0.07 $\mathrm{mmol})$, methyl acrylate $(4 \mu \mathrm{L}, 0.07 \mathrm{mmol})$ and $11.0 \mathrm{mg}$ of AIBN 
(0.007 mmol). The reaction was complete after $70 \mathrm{~min}$ at $50{ }^{\circ} \mathrm{C}$. Yield: $20.0 \mathrm{mg}(0.03 \mathrm{mmol}), 44 \%$. Anal. calcd for $\mathrm{C}_{30} \mathrm{H}_{36} \mathrm{AuNO}_{3}$ : C, 54.96; H, 5.54; N, 2.14. Found: C, 54.23; H, 5.78; N, 2.68. ${ }^{1} \mathrm{H}-$ NMR (300.13 MHz, $\mathrm{CD}_{2} \mathrm{Cl}_{2}$ ): $\delta 7.75\left(\mathrm{~d}, 2 \mathrm{H},{ }^{4} J=1.6 \mathrm{~Hz}, \mathrm{H} 8\right), 7.55$ (d, $\left.2 \mathrm{H},{ }^{3} \mathrm{~J}=8.1 \mathrm{~Hz}, \mathrm{H} 5\right), 7.27$ (dd, $\left.2 \mathrm{H},{ }^{3} \mathrm{~J}=8.1,{ }^{4} \mathrm{~J}=1.6 \mathrm{~Hz}, \mathrm{H} 6\right)$, 6.95 (s, 2H, H2), 4.00 (s, 3H, OMe), 3.59 (s, 3H, COOMe), 2.84 (t, $\left.2 \mathrm{H},{ }^{3} J=8.0 \mathrm{~Hz}, \mathrm{H} 12\right), 2.10\left(\mathrm{t}, 2 \mathrm{H},{ }^{3} J=8.0 \mathrm{~Hz}, \mathrm{H} 13\right), 1.38 \mathrm{ppm}(\mathrm{s}$, 18H, H11). ${ }^{13} \mathrm{C}\left\{{ }^{1} \mathrm{H}\right\}$ NMR (75.47 MHz, $\mathrm{CD}_{2} \mathrm{Cl}_{2}$ ): $\delta 175.7$ (s, COOMe), 170.6 (s, C1), 167.3 (s, C9), 164.3 (s, C3), 154.2 (s, C7), 148.2 (s, C4), 130.4 (s, C8), 125.0 (s, C5), 123.4 (s, C6), 102.4 (s, C2), 56.4 (s, OMe), 51.6 (s, COOMe), 35.2 (s, C10), 31.4 (s, C11), 25.4 (s, C12), $18.1 \mathrm{ppm}$ (s, C13).

$\left(\mathrm{C}^{\wedge} \mathrm{N}^{\mathrm{OMe}}{ }_{\wedge} \mathrm{C}\right) \mathrm{Au}\left(\mathrm{CH}_{2}\right)_{2} \mathrm{COOH}(4)$.<smiles></smiles>

This compound was synthesized from 1 (40.0 mg, 0.07 mmol), acrylic acid ( $4 \mu \mathrm{L}, 0.07 \mathrm{mmol}$ ) and $11.0 \mathrm{mg}$ of AIBN $(0.007 \mathrm{mmol})$, and the reaction resulted complete after $80 \mathrm{~min}$ at $50{ }^{\circ} \mathrm{C}$. Yield: $20.5 \mathrm{mg}(0.04 \mathrm{mmol}), 56 \%$. Anal. calcd for $\mathrm{C}_{29} \mathrm{H}_{34} \mathrm{AuNO}_{3}$ : C, 54.29; H, 5.34; N, 2.18. Found: C, 53.73; H, 5.45; N, 2.76. ${ }^{1} \mathrm{H}-\mathrm{NMR}\left(300.13 \mathrm{MHz}, \mathrm{CD}_{2} \mathrm{Cl}_{2}\right): \delta 7.78\left(\mathrm{~d}, 2 \mathrm{H},{ }^{4} \mathrm{~J}=\right.$ $1.4 \mathrm{~Hz}, \mathrm{H} 8$ ), 7.56 (d, $\left.2 \mathrm{H},{ }^{3} \mathrm{~J}=8.2 \mathrm{~Hz}, \mathrm{H} 5\right), 7.28$ (dd, $2 \mathrm{H},{ }^{3} \mathrm{~J}=8.2,{ }^{4} J$ $=1.4 \mathrm{~Hz}, \mathrm{H} 6), 6.97(\mathrm{~s}, 2 \mathrm{H}, \mathrm{H} 2), 4.01(\mathrm{~s}, 3 \mathrm{H}, \mathrm{OMe}), 2.89\left(\mathrm{t}, 2 \mathrm{H},{ }^{3} J\right.$ $=8.0 \mathrm{~Hz}, \mathrm{H} 12), 2.13\left(\mathrm{t}, 2 \mathrm{H},{ }^{3} J=8.0 \mathrm{~Hz}, \mathrm{H} 13\right), 1.38 \mathrm{ppm}(\mathrm{s}, 18 \mathrm{H}$, H11). ${ }^{13} \mathrm{C}\left\{{ }^{1} \mathrm{H}\right\}$ NMR (75.47 MHz, $\left.\mathrm{CD}_{2} \mathrm{Cl}_{2}\right): \delta 179.3$ (s, COOH), 170.7 (s, C1), 167.2 (s, C9), 164.4 (s, C3), 154.4 (s, C7), 148.3 (s, C4), 130.4 (s, C8), 125.1 (s, C5), 123.5 (s, C6), 102.4 (s, C2), 56.5 (s, OMe), 35.6 (s, C10), 31.4 (s, C11), 25.4 (s, C12), 17.4 ppm (s, C13).

$\left(\mathrm{L}^{\mathrm{OMe}}\right) \mathrm{Au}\left(\mathrm{CH}_{2}\right)_{2} \mathrm{Ph}(5)$.

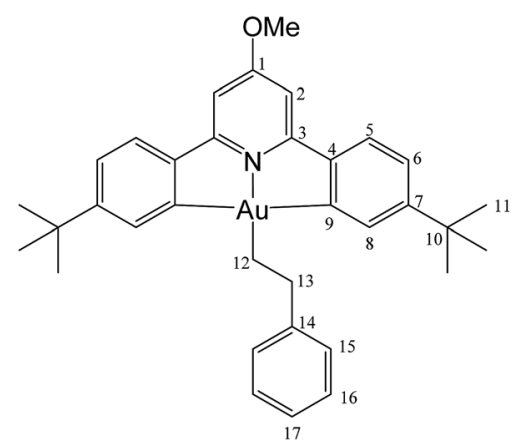

This compound was synthesized from 1 (40.0 mg, 0.07 $\mathrm{mmol})$, styrene $(4 \mu \mathrm{L}, 0.07 \mathrm{mmol})$ and $11.0 \mathrm{mg}$ of AIBN (0.007 $\mathrm{mmol})$. The reaction was complete after $8 \mathrm{~h}$ at $50{ }^{\circ} \mathrm{C}$. Yield: $6.0 \mathrm{~g}$ (0.009 mmol), 13\%. Anal. calcd for $\mathrm{C}_{34} \mathrm{H}_{38} \mathrm{AuNO}$ : C, 60.62; $\mathrm{H}$,
5.69; N, 2.08. Found: C, 59.92; H, 5.78; N, 2.48. ${ }^{1} \mathrm{H}-\mathrm{NMR}(300.13$ $\left.\mathrm{MHz}, \mathrm{CD}_{2} \mathrm{Cl}_{2}\right): \delta 7.81\left(\mathrm{~d}, 2 \mathrm{H},{ }^{4} J=1.8 \mathrm{~Hz}, \mathrm{H} 8\right), 7.54\left(\mathrm{~d}, 2 \mathrm{H},{ }^{3} J=\right.$ $8.1 \mathrm{~Hz}, \mathrm{H} 5), 7.38$ (d, 2H, $\left.{ }^{3} J=7.4 \mathrm{~Hz}, \mathrm{H} 15\right), 7.29$ (m, 4H, H6 + H16), 7.16 (t, 1H, $\left.{ }^{3} J=7.4 \mathrm{~Hz}, \mathrm{H} 17\right), 6.94$ (s, 2H, H2), 3.99 (s, 3H, OMe), $3.16\left(\mathrm{t}, 2 \mathrm{H},{ }^{3} \mathrm{~J}=8.2 \mathrm{~Hz}, \mathrm{H} 12\right), 2.14\left(\mathrm{t}, 2 \mathrm{H},{ }^{3} \mathrm{~J}=8.2 \mathrm{~Hz}\right.$, H13), $1.40 \mathrm{ppm}(\mathrm{s}, 18 \mathrm{H}, \mathrm{H} 11) .{ }^{13} \mathrm{C}\left\{{ }^{1} \mathrm{H}\right\} \mathrm{NMR}(75.47 \mathrm{MHz}$, $\mathrm{CD}_{2} \mathrm{Cl}_{2}$ ): $\delta 170.6$ (s, C1), 167.6 (s, C9), $164.2(\mathrm{~s}, \mathrm{C} 3), 154.1$ (s, C7), 148.4 (s, C4), 146.6 (s, C14), 130.4 (s, C8), 128.7 (s, C15 or C16), 128.7 (s, C15 or C16), 125.7 (s, C17), 125.0 (s, C5), 123.4 (s, C6), 102.4 (s, C2), 56.5 (s, OMe), 38.0 (s, C12), 35.6 (s, C10), 31.5 (s, C11), 27.6 ppm (s, C13).

$\left(\mathrm{C}^{\wedge} \mathrm{N}^{\mathrm{OMe}}{ }^{\wedge} \mathrm{C}\right) \mathrm{Au}\left(\mathrm{CH}_{2}\right)_{2}\left(2-\mathrm{MeC}_{6} \mathrm{H}_{4}\right)(6)$.<smiles></smiles>

This compound was synthesized from $1(40.0 \mathrm{mg}, 0.07$ $\mathrm{mmol}), 2$-methylstyrene ( $6 \mu \mathrm{L}, 0.07 \mathrm{mmol})$ and $11.0 \mathrm{mg}$ of AIBN $(0.007 \mathrm{mmol})$, and the reaction resulted complete after $6 \mathrm{~h}$ at $50{ }^{\circ} \mathrm{C}$. Anal. yield: $19.0 \mathrm{~g}(0.027 \mathrm{mmol}), 39 \%$. Calcd for $\mathrm{C}_{33} \mathrm{H}_{40}$ AuNO: C, 61.13; H, 5.86; N, 2.04. Found: C, 60.65; H, 5.36; N, 2.38. ${ }^{1} \mathrm{H}-\mathrm{NMR}\left(300.13 \mathrm{MHz}, \mathrm{CD}_{2} \mathrm{Cl}_{2}\right): \delta 7.85$ (d, $2 \mathrm{H},{ }^{4} \mathrm{~J}=$ $1.8 \mathrm{~Hz}, \mathrm{H} 8$ ), 7.57 (d, 2H, $\left.{ }^{3} \mathrm{~J}=8.2 \mathrm{~Hz}, \mathrm{H} 5\right), 7.35$ (d, $2 \mathrm{H},{ }^{3} J=7.2 \mathrm{~Hz}$, H15), 7.28 (dd, 2H, $\left.{ }^{3} J=8.2,{ }^{4} J=1.8 \mathrm{~Hz}, \mathrm{H} 6\right), 7.14$ (m, 2H, H16 + H18), 7.08 (t, 1H, $\left.{ }^{3} J=7.2 \mathrm{~Hz}, \mathrm{H} 17\right), 6.96$ (s, 2H, H2), 4.0 (s, 3H, $\mathrm{OMe}$ ), 3.15 (t, 2H, $\left.{ }^{3} \mathrm{~J}=8.7 \mathrm{~Hz}, \mathrm{H} 12\right), 2.51$ (s, 3H, Me), 2.07 (t, 2H, $\left.{ }^{3} J=8.7 \mathrm{~Hz}, \mathrm{H} 13\right), 1.39 \mathrm{ppm}(\mathrm{s}, 18 \mathrm{H}, \mathrm{H} 11) .{ }^{13} \mathrm{C}\left\{{ }^{1} \mathrm{H}\right\} \mathrm{NMR}(75.47$ $\mathrm{MHz}, \mathrm{CD}_{2} \mathrm{Cl}_{2}$ ): $\delta 170.6$ (s, C1), 167.6 (s, C9), 164.2 (s, C3), 154.1 (s, C7), 148.4 (s, C4), 144.5 (s, C14), 135.9 (s, C19), 130.5 (s, C15), 130.5 (s, C8), 129.5 (C16), 125.6 (s, C17 or C18), 125.9 (C17 or C18), 125.1 (s, C5), 123.4 (s, C6), 102.4 (s, C2), 56.4 (s, OMe), 35.6 (s, C10), 35.2 (s, C12), 31.6 (s, C11), 25.9 (s, C13), 19.8 ppm (s, $\mathrm{Me})$.

$$
\left(\mathrm{C}^{\wedge} \mathrm{N}^{\mathrm{OMe}}{ }_{\wedge} \mathrm{C}\right) \mathrm{Au}\left(\mathrm{CH}_{2}\right)_{2}\left(3-\mathrm{MeC}_{6} \mathrm{H}_{4}\right)(7) \text {. }
$$

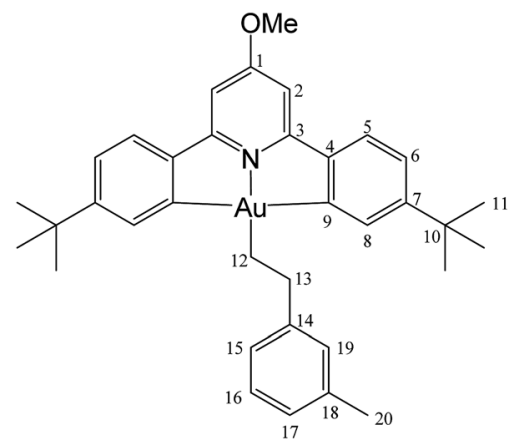

This compound was synthesized from 1 (40.0 mg, 0.07 mmol), 3-methylstyrene ( $9 \mu \mathrm{L}, 0.07 \mathrm{mmol}$ ) and $11.0 \mathrm{mg}$ of AIBN 
$(0.007 \mathrm{mmol})$, and the reaction resulted complete after $8 \mathrm{~h}$ at $50{ }^{\circ} \mathrm{C}$. Yield: $12.0 \mathrm{mg}(0.02 \mathrm{mmol}), 25 \%$. Calcd for $\mathrm{C}_{33} \mathrm{H}_{40} \mathrm{AuNO}$ : C, 61.13; H, 5.86; N, 2.04. Found: C, 61.82; H, 5.97; N, $1.85 .{ }^{1} \mathrm{H}-$ NMR (300.13 MHz, $\mathrm{CD}_{2} \mathrm{Cl}_{2}$ ): 7.83 (d, 2H, $\left.{ }^{4} \mathrm{~J}=1.9 \mathrm{~Hz}, \mathrm{H} 8\right), 7.58$ (d, $\left.2 \mathrm{H},{ }^{3} \mathrm{~J}=8.1 \mathrm{~Hz}, \mathrm{H} 5\right), 7.29$ (dd, $\left.2 \mathrm{H},{ }^{3} \mathrm{~J}=8.1,{ }^{4} \mathrm{~J}=1.9 \mathrm{~Hz}, \mathrm{H} 6\right)$, 7.20 (m, 3H, H15 + H17 + H19), 6.98 (m, 3H, H2 + H16), 4.0 (s, $3 \mathrm{H}, \mathrm{OMe}), 3.11\left(\mathrm{t}, 2 \mathrm{H},{ }^{3} \mathrm{~J}=8.1 \mathrm{~Hz}, \mathrm{H} 12\right), 2.33$ (s, 3H, Me), $2.14(\mathrm{t}$, $\left.2 \mathrm{H},{ }^{3} J=8.1 \mathrm{~Hz}, \mathrm{H} 13\right), 1.40 \mathrm{ppm}(\mathrm{s}, 18 \mathrm{H}, \mathrm{H} 11) .{ }^{13} \mathrm{C}\left\{{ }^{1} \mathrm{H}\right\} \mathrm{NMR}$ (75.47 MHz, $\mathrm{CD}_{2} \mathrm{Cl}_{2}$ ): $\delta 170.6$ (s, C1), 167.6 (s, C9), 164.2 (s, C3), 154.1 (s, C7), 148.4 (s, C4), 146.5 (s, C14), 138.2 (s, C19), 130.4 (s, C8), 129.6 (s, C15), 128.6 (C16), 126.5 (s, C17 or C18), 125.6 (C17 or C18), 125.1 (s, C5), 123.4 (s, C6), 102.4 (s, C2), 56.4 (s, OMe), 37.9 (s, C12), 35.6 (s, C10), 31.5 (s, C11), 27.7 (s, C13), 21.6 ppm (s, Me).

$\left(\mathrm{C}^{\wedge} \mathrm{N}^{\mathrm{OMe}}{ }_{\wedge} \mathrm{C}\right) \mathrm{Au}\left(\mathrm{CH}_{2}\right)_{2} \mathrm{C}(\mathrm{O}) \mathrm{Me}(8)$.

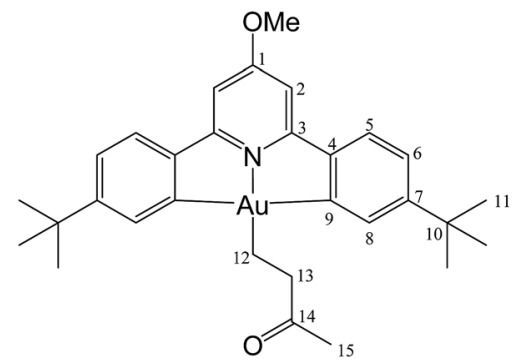

This compound was synthesized from 1 (40.0 mg, 0.07 $\mathrm{mmol}), 3$-buten-2-one ( $6 \mu \mathrm{L}, 0.07 \mathrm{mmol}$ ) and $11.0 \mathrm{mg}$ of AIBN $(0.007 \mathrm{mmol})$. The reaction was complete after $60 \mathrm{~min}$ at $50{ }^{\circ} \mathrm{C}$. Yield: $35.0 \mathrm{mg}(0.06 \mathrm{mmol}), 78 \%$. Anal. calcd for $\mathrm{C}_{30} \mathrm{H}_{36} \mathrm{AuNO}_{2}$ : C, 56.34; H, 5.67; N, 2.19. Found: C, 56.21; H, 5.57; N, 2.30. ${ }^{1} \mathrm{H}-$ NMR (300.13 MHz, $\mathrm{CD}_{2} \mathrm{Cl}_{2}$ ): $\delta 7.74\left(\mathrm{~d}, 2 \mathrm{H},{ }^{4} J=1.4 \mathrm{~Hz}, \mathrm{H} 8\right), 7.57$ (d, $\left.2 \mathrm{H},{ }^{3} \mathrm{~J}=8.2 \mathrm{~Hz}, \mathrm{H} 5\right), 7.28$ (dd, $\left.2 \mathrm{H},{ }^{3} \mathrm{~J}=8.2,{ }^{4} \mathrm{~J}=1.4 \mathrm{~Hz}, \mathrm{H} 6\right)$, 6.97 (s, 2H, H2), 4.01 (s, 3H, OMe), 2.93 (t, 2H, $\left.{ }^{3} J=8.1 \mathrm{~Hz}, \mathrm{H} 12\right)$, 2.93 (s, 3H, Me), 2.20 (t, 2H, $\left.{ }^{3} J=8.1 \mathrm{~Hz}, \mathrm{H} 13\right), 1.37 \mathrm{ppm}(\mathrm{s}, 18 \mathrm{H}$, H11). ${ }^{13} \mathrm{C}\left\{{ }^{1} \mathrm{H}\right\}$ NMR (75.47 MHz, $\mathrm{CD}_{2} \mathrm{Cl}_{2}$ ): $\delta 210.6$ (s, $\left.C(\mathrm{O}) \mathrm{Me}\right)$, 170.6 (s, C1), 167.3 (s, C9), 164.2 (s, C3), 154.2 (s, C7), 148.3 (s, C4), 130.3 (s, C8), 125.1 (s, C5), 123.5 (s, C6), 102.4 (s, C2), 56.4 (s, OMe), 45.4 (s, C(O)Me), 35.6 (s, C10), 31.4 (s, C11), 29.6 (s, C12), 17.4 ppm (s, C13).

\section{DFT calculations}

Theoretical calculations were performed at the Density Functional Theory (DFT) level ${ }^{14}$ using the Gaussian 09 package of programs. ${ }^{15}$ Geometry optimizations were carried out using the PBE0 (PBE1PBE) hybrid functional, ${ }^{16}$ along with the Schäfer, Horn, and Ahlrichs double- $\zeta$ plus polarization all-electron basis sets $^{17}$ for all atomic species. The nature of the minima of each optimized structure was verified by harmonic frequency calculations. The software Chemissian ${ }^{\mathbf{1 8}}$ was used for the preparation of spin density distribution figures.

\section{Conflicts of interest}

The authors declare no conflict of interest.

\section{Acknowledgements}

This work was supported by the European Research Council. M. B. is an ERC Advanced Investigator Award holder (grant no. 338944-GOCAT).

\section{References}

1 D.-A. Roşca, D. A. Smith, D. L. Hughes and M. Bochmann, Angew. Chem., Int. Ed., 2012, 51, 10643.

2 D.-A. Roşca, J. A. Wright and M. Bochmann, Dalton Trans., 2015, 44, 20785.

3 R. Kumar and C. Nevado, Angew. Chem., Int. Ed., 2017, 56, 2, and references cited therein.

4 N. Savjani, D.-A. Roşca, M. Schormann and M. Bochmann, Angew. Chem., Int. Ed., 2013, 52, 874.

5 L. Rocchigiani, J. Fernandez-Cestau, G. Agonigi, I. Chambrier, P. H. M. Budzelaar and M. Bochmann, Angew. Chem., Int. Ed., 2017, 56, 13861.

6 D.-A. Roșca, J. Fernandez-Cestau, J. Morris, J. A. Wright and M. Bochmann, Sci. Adv., 2015, 1, e1500761.

7 D. -A. Roşca, J. A. Wright, D. L. Hughes and M. Bochmann, Nat. Commun., 2013, 4, 2167.

8 A. Pintus, L. Rocchigiani, J. Fernandez-Cestau, P. H. M. Budzelaar and M. Bochmann, Angew. Chem., Int. Ed., 2016, 55, 12321.

9 (a) B. Sahoo, M. N. Hopkinson and F. Glorius, J. Am. Chem. Soc., 2013, 135, 5505; (b) A. Tlahuext-Aca, M. N. Hopkinson, B. Sahoo and F. Glorius, Chem. Sci., 2016, 7, 89; (c) M. S. Winston, W. J. Wolf and F. D. Toste, J. Am. Chem. Soc., 2014, 136, 7777; (d) X.-Z. Shu, M. Zhang, Y. He, H. Frei and F. D. Toste, J. Am. Chem. Soc., 2014, 136, 5844; (e) S. Kim, J. Rojas-Martin and F. D. Toste, Chem. Sci., 2016, 7, 85; (f) D. V. Patil, H. Yun and S. Shin, Adv. Synth. Catal., 2015, 357, 2622; $(g)$ L. Huang, F. Rominger, M. Rudolph and A. S. K. Hashmi, Chem. Commun., 2016, 52, 6435; (h) L. Huang, M. Rudolph, F. Rominger and A. S. K. Hashmi, Angew. Chem., Int. Ed., 2016, 55, 4808.

10 (a) D. A. Smith, D.-A. Roşca and M. Bochmann, Organometallics, 2012, 31, 5988; (b) E. Langseth, C. H. Görlitz, R. H. Heyn and M. Tilset, Organometallics, 2012, 31, 6567.

11 W.-P. To, G. S. M. Tong, C.-W. Cheung, C. Yang, D. Zhoua and C.-M. Che, Inorg. Chem., 2017, 56, 5046.

12 J. Fernandez-Cestau, B. Bertrand, A. Pintus and M. Bochmann, Organometallics, 2017, 36, 3304.

13 I. Chambrier, D.-A. Roşca, J. Fernandez-Cestau, D. L. Hughes, P. H. M. Budzelaar and M. Bochmann, Organometallics, 2017, 36, 1358.

14 W. Koch and M. C. Holthausen, A Chemist's Guide to Density Functional Theory, Wiley-VCH, Weinheim, Germany, 2nd edn, 2002.

15 M. J. Frisch, G. W. Trucks, H. B. Schlegel, G. E. Scuseria, M. A. Robb, J. R. Cheeseman, G. Scalmani, V. Barone, B. Mennucci, G. A. Petersson, H. Nakatsuji, M. Caricato, X. Li, H. P. Hratchian, A. F. Izmaylov, J. Bloino, G. Zheng, J. L. Sonnenberg, M. Hada, M. Ehara, K. Toyota, 
R. Fukuda, J. Hasegawa, M. Ishida, T. Nakajima, Y. Honda, O. Kitao, H. Nakai, T. Vreven, J. A. Montgomery Jr, J. E. Peralta, F. Ogliaro, M. Bearpark, J. J. Heyd, E. Brothers, K. N. Kudin, V. N. Staroverov, T. Keith, R. Kobayashi, J. Normand, K. Raghavachari, A. Rendell, J. C. Burant, S. S. Iyengar, J. Tomasi, M. Cossi, N. Rega, J. M. Millam, M. Klene, J. E. Knox, J. B. Cross, V. Bakken, C. Adamo, J. Jaramillo, R. Gomperts, R. E. Stratmann, O. Yazyev, A. J. Austin, R. Cammi, C. Pomelli, J. W. Ochterski, R. L. Martin, K. Morokuma,
V. G. Zakrzewski, G. A. Voth, P. Salvador, J. J. Dannenberg, S. Dapprich, A. D. Daniels, O. Farkas, J. B. Foresman, J. V. Ortiz, J. Cioslowski, D. J. Fox, Gaussian 09, Revision C.01, Gaussian, Inc., Wallingford CT, 2010.

16 C. Adamo and V. Barone, J. Chem. Phys., 1999, 110, 6158.

17 A. Schäfer, H. Horn and R. Ahlrichs, J. Chem. Phys., 1992, 97, 2571.

18 L. V. Skripnikov, Chemissian V. 4.43, Visualization Computer Program, http://www.chemissian.com, 2016. 